\title{
The Role Performance of the Inspectorate Division of the Ministry of Education in Inspecting Secondary Schools in Adamawa State of Nigeria
}

\author{
Kabiru Mohammed Badau, ${ }^{1, *}$ \\ ${ }^{1}$ Department of Science Education, ModibboAdama University of Technology, Yola, Adamawa State, Nigeria \\ *Correspondence: Department of Science Education, ModibboAdama University of Technology, Yola, P.M.B. 2076, \\ Adamawa State, Nigeria. Tel: 234-803-806-8439. E-mail: badaubadau@yahoo.com
}

Received: January 24, 2014

Accepted: February 14, $2014 \quad$ Online Published: August 4, 2014

doi:10.5430/wje.v4n4p70

URL: http://dx.doi.org/10.5430/wje.v4n4p70

\begin{abstract}
This is a survey study carried out in Adamawa State of Nigeria to determine the role performance of the inspectorate division of the ministry of education in inspecting secondary schools. Sixty (60) principals and 60 teachers which were proportionately stratified along five educational zones of Adamawa State, participated in the study. A close ended questionnaire was used to collect the relevant data for the study. The instrument sought information on role performance of the inspectorate division on types of inspection visits, feedback on inspection, inspection reports, curriculum innovations and impact of inspection in secondary schools. Data was analysed through Z-test and factorial analysis of variance. Results of the analysis of responses from the questionnaire include that, the role performance of the inspectorate division of the ministry of education on types of inspection visits and feedback on inspection is low. The role performance of theinspectorate division on inspection reports, curriculum innovations and impact of inspection is high. Finally, the result shows that the role performance of the inspectorate division on the five factors of performance is low. It was recommended among others that adequate and qualified human and material resources should be provided in the inspectorate division by the federal and state ministries of education to make the role performance of the division high in secondary schools.
\end{abstract}

Keywords: role performance; inspectorate division; ministry of education; secondary schools

\section{Introduction}

The concept of inspection is as old as western education in Nigeria. It can be traced to the 1882 Education Ordinance when it became a government concern. It was the first attempt by the Colonial Administration to establish a form of control over the growth and development of schools (Kolawole, 2012).

Inspection means assessing the state of teaching and learning with the aim of improving educational standards (Aiyepeku, 1983). One can thus say that inspection is concerned with the evaluation and control of the education with a view to raising standard and quality of education in general. Another term used synonymous with inspection in this context is supervision: Longe (1986) sees supervision as an aspect of administration specifically concerned with ensuring that teachers are forced to certain standard of performance on their job. Therefore, whenever supervision occurs in the school system, it is a sign of concern for the quality of instruction. These two terms 'inspection' and 'supervision' in the educational system is intended to serve as means of quality control. As such the two words can be used interchangeably as synonyms in this context and they are both taken as quality control activities which aim at either maintaining or improving quality of teaching and learning in schools.

The aim of inspection and supervision is to improve instructions in schools and assist in maintaining standard of education in any education system. In this case, inspection has to be efficient and effective through role performance by the inspectorate division of the ministry of education. Realizing the importance of effective inspectorate and supervisory services to schools, the Federal Government of Nigeria made it clear and emphasized in the National Policy on Education (2008) that the new system of education must be sufficiently backed with adequate and effective supervisory and inspectorate services. The policy put the responsibility of ensuring quality control and uniform standard in education on the Federal Ministry of Education (FME) and the Ministries of Education at the state level through the federal inspectorate services (FIS) at the Federal level and Inspectorate Departments at the State level. 
The federal inspectorate service of the Federal and State Ministries of Education according to Ochuba (2009) is directly responsible for quality control and maintenance of standards in institutions below the tertiary institutions. This is backed by Decree 16 of 20th August, 1985 which outlined its objectives to include:

- To maintain minimum standard in education practice nationwide.

- To operate common system of education practice nationwide.

- To introduce classroom innovation.

- To achieve quality education in Nigeria.

The role of Inspector of Education, according to Giwa (2005) includes leading teams or inspectors on supervising duties. He also performs some administrative functions and consultant, coordinates activities in the inspectorate division. The quality of education is believed to be getting poorer due to non-effective inspection (Obemeata, 1995). The decline in the quality of education in the country requires quality control measures by the inspectorate department. The inspectorate department is the organ of surveillance and quality control in the Ministries of Education at both federal and state levels. According to Aiyepeku (1982) the Inspectorate is commonly referred to as the "eyes" and "ears" of the Ministry of Education in the monitoring of the educational system.

There exists difference between the roles mandated and the extent to which those roles are actually performed (Singh \&Rai, 2013). However, merely mandating the importance of inspection and roles of the inspectorate is not a guarantee of achieving the stated goals of inspection.

From the forgoing, it is evident that the role performance of the inspectorate in a school system especially in the secondary schools in Nigeria is very crucial. Thus, for effective supervision of instruction, inspectors should be able to perform their variegated roles as expected if the goals of education are to be attained. Hence, the need for this research.

\subsection{Statement of the Problem}

A considerable decline has however, been observed in the role performance of the inspectorate division by educational administrators (Tunde, 1980). The role performance of the inspectorate division of the Ministry of Education at the state and federal levels have not lived to expectation. This is because the inspectorate service is plaqued by a number of issues and challenges (Ochuba, 2009). More specifically, the pedagogical inspection that has direct bearing on improvement of the teaching learning-practices and the overall quality of schools has been subdued by the importance given to the control functions. A study carried out by Aiyepeku (1987) to determine the effect of inspection on pedagogical performance revealed that school inspection have little or no effect on student performance. It also indicated that inspection visits have no positive effect in schools with average results. Despite effort at quality control, there are complaints about the quality of education given in our schools and many people say that school inspection and supervision is ineffective (Alade, 2002).

The falling standard of education is caused by ineffective inspectorate system which is one of the services for education in terms of quality control (Badau, 1992). The disappointment in the role performance of the inspectorate division in secondary schools is responsible for their deplorable state in terms of infrastructural facilities, equipment, teaching staff and student personnel services. A consequence of this is that necessary steps to improve the quality of teaching and learning have not been taken and it has been confirmed that this leads to continued poor performance of pupils. This study will assist the Federal and State Ministries of Education in wakening up the role performance of the inspectorate, the running of school administration and reforming the overall educational policies of Adamawa State of Nigeria. It is as a result of the importance of inspectorate services in education for quality improvement that stimulated the author to venture into the study. This is to asses the role performance of the inspectorate division for quality improvement in secondary schools in Adamawa State of Nigeria.

\subsection{Purpose of the Study}

Themain purpose of the study was toassess the role performance of the inspectorate division of the Ministry of Education in inspecting secondary schools in Adamawa State of Nigeria. Specifically, the study determined:

1. the role performance of the inspectorate division on types of inspection visits in secondary schools.

2. the role performance of the inspectorate division on feed back on inspection in secondary schools.

3. the role performance of the inspectorate division on inspection reports in secondary schools.

4. the role performance of the inspectorate division on curriculum innovation in secondary schools. 
5. the role performance of the inspectorate division on the impact of inspection in secondary schools.

6. the role performance of the inspectorate division on the five factors determining performance of the division in secondary schools.

\subsection{Hypotheses}

The following hypotheses were generated for the study.

$\mathrm{H}_{01} \quad$ There is no significant difference between the opinions of principals and teachers on the types of inspection visits in secondary schools.

$\mathrm{H}_{02}$ There is no significant difference in the opinions of principals and teachersregarding feedback on inspection in secondary schools.

$\mathrm{H}_{03} \quad$ There is no significant difference between the opinions of principals and teachers on inspection reports in secondary schools.

$\mathrm{H}_{04} \quad$ There is no significant difference in the opinions of principals and teachers on curriculum innovations in secondary schools.

$\mathrm{H}_{05} \quad$ There is no significant difference in the opinions of principals and teachers on the impact of inspection in secondary schools.

$\mathrm{H}_{06} \quad$ There is no significant difference among the opinions of principals and teacherson the factors determining the performance of the division insecondary schools.

\subsection{Theoretical Framework}

School inspection as external evaluation in education has a long history in the world and it can be traced back to the $18^{\text {th }}$ century in European Countries (Grauwe, 2007). However, school inspection as an organ of quality assurance in education gained its strength in connection to the introduction of classical management theories. These include: the scientific management in 1880s by Fredrick Winston Taylor, Administrative Management in 1940s by Henri Fayol and Bureaucratic Management in 1920s by Max Weber (Wertheim, 2007. Sergiovanni \& Starratt, 2007). All of these management thoughts were concerned on how to manage work and organizations more efficiently (Maytete, 2009). Human Relations theory had its origin in the Democratic movement as propounded by Elton Mayo in 1930s. He believed that the product of worker could increase by meeting their social needs at work and by promoting interaction between them. According to Elton Mayo, workers need to be treated decently and should be involved in decision making process (Sergio Vanni\&Starratt, 2007). In education and schooling process, teachers are regarded as whole persons in their own right rather than as packages of energy, stalls and aptitudes to be utilized by administrators and school inspectors.

Critical theory was propounded by the five Frankfort School theoreticians: Herbert Marcuse, Theodor Adorno, MaxHorkheimer, Walter Benjamin and Erich Fromm. It was developed from new Marxist Philosopy of the Frank School developed in Germany in 1930s. Critical theory calls for educational theory to accept the need to employ interpretative categories in different phenomena. Interpretivists content that there should be respect and difference between people and the objects of the natural science Critical theory is also featured by the claim that educational status should be determined by the way it relates to practice (Carr\&Kemmis, 1986). This study draws upon critical theory since it advocates freedom and emancipation process. It also gives more voice to teachers as the key players and implementers of the curriculum in the school inspection system. Teachers are regarded as people with freewill and with total freedom (Mac Isaac, 1996). They are considered to be conscious about their strength and weakness (Druker, 1991). When school inspectors recognise that teachers are free entities with their own thinking, their role as inspectors is to facilitate the teaching and learning process and not dictate what should be done by the teacher. Teachers are to be encouraged to reflect on their teaching and learning practices. What should be done by the teacher weakness and try to find the solutions of the problems that face them in teaching and learning (Tripp, 1992).

As scientific management theory puts forward that teacher cannot be left free to do whatever she/he wishes to do. Some rules and regulations are to be applicable with a mixture of human if the national goals and objectives are to be achieved. Some rules and regulations are also to be applicable as per desires and requirements of organization, institutes and society as well. Giwa (2005) conceived inspection involvement as a result of the view of scientific management where in management felt that workers are lazy and needed to be pushed or coerced, workers had to be closely supervised. Modern supervision evolved as a result of human relation movement by which management thought that workers have initiatives that they could perform well on the job without close supervision and that they could be efficiently and effectively mobilized towards mass production without being forced or coerced. This 
management human relation view is also related to the democratic concept of supervision which encourage cooperative practices in supervision.

\section{Review of Literature}

A substantial segment of research literature focuses upon the expected roles and functions of the inspectorate/inspectors but little of it for determining the role performance of the inspectorate division in secondary schools. A consideration of the actual roles inspectors perform should lead to findings over whether current expectations of the roles are realistic (Lillis, 1992). On the impact of the new inspection regime, office for standard in education (Ofsted) (2007) reported that vast majority of schools were satisfied in the inspection process. The schools reported that they were implementing all or most of the recommendations for improvement. Most schools took the view that the inspection had contributed to school improvement (Maccrone, Rudd, Blenkinsop, Wade, Rutt, \&Yestianewe, 2007). Rosenthal (2004) found out that there exist a small but well determined adverse negative effect associated with of stedinspection event for the year of the inspection. Chapman (2001) study, found out that Ofsted has only made limited contributions towards school development and improvements effort. The Ofsted itself claim that inspection promoted improvement at both national level and also school level.

In a study carried out by Riches (1992), inspection reports were uneven. Some seem sketchy and vague are consequently misleading. Criteria set out for evaluating school was not made available to the inspectorate. The study further indicated that inspectors are not making evaluation of schools in the same rigorous way students are being assessed. Out comes of inspection suffer deficiencies of precision, organsation and utilization, lack of systematic feedback to decision making centres (Carlos, 1984). They are ignorant of what has happened or is happening in respect of planned changes or only know about them $\mathrm{n}$ a general way without precise information or analysis of interaction (Carlos, 1984). Normal feedback does not occupy inspectors very much nor is it apparently demanded by their superiors.

Shaheen (2013) in her study, found that school inspectors perform their role towards improving teaching and learning. Teachers also perceived advice and feedback given through inspection reports and recommendations useful for making improvements in their own work performance. In a systematic review of fourteen articles by Klerks (2012) which discuss various types of research on measurement of effect of school inspections on outcomes, no evidence has been found that school inspections automatically lead to the improvement of education quality. Also, it was not concluded that characteristic of school inspection themselves lead to the improvement of education quality. Instead, research shows that in practice there is a complex interaction between different characteristics of school inspections and the inspector on one hand and the school with its pupils, teachers and management on the other.

Njoku (1983) study concluded that feedback on inspection does not lead to behavioural change of teachers. It also became clear that feedback that is given to stimulate the development of teachers is appropriate, provided that the inspectors get feedback training. A study carried out by Hommeier and Kluth (2011) on the impact of inspection revealed that the quality of teaching improved nearby to the level by schools that did not fail the first inspection. Whether these improvements have an impact on students' achievements results has not be studied yet.

Gokce \& Kantos (2012) study found that inspectors manners such as shouting, being angry, humiliating, scolding, being serious, controlling and taking notes, staring the students and carrying and playing ruler in his/her hands frightened the students. Besides, the students liked inspectors who were friendly, kind, neatly and well-dressed and who made jokes and used good communication skills. Erhren, Leeuni \& Scheerens (2008) concluded that the framework programme theory had no impact on the Dutch Educational supervision act for school improvement.

Machumu (2012) in his study, revealed that secondary school teachers had positive attitude towards school inspection. Some school inspectors still had elements of the traditional approach to school inspection being conservative and reluctant to accept changes in the roles of school inspection and practice. A performance audit of school inspection in Tanzania show that school inspection do not address the problem of poor performance studentsin secondary schools (The United Republic of Tanzania, 2008). There are also indicators that information (feedback) from the inspectorate is not used in a suitable way. The main part of the recommendations in the school inspection reports are not appropriately addressed. The efficiency of supervision in the schools is hampered by lack of support from the inspectorate, poor quality of teaching and learning resulted to poor performance in external examinations. Inspection and supervision of secondary schools have not been effective. The provision of quality education for all has still not been met.

Shaheen (2013) in his study found that there is no significant difference between male and female school head on 
their perception of school inspection. There is no significant difference between experience and inexperience primary school head in their perception of school inspection. There is no signification difference in the perception of primary school head on schoolinspection base on age. It showed Poor attitude of primary school heads towards school inspection.

In a study carried out by Ijaiya and Fasasi (2008), inspection visits conducted by State and Federal inspectorate were not adequate and their integrity was high. Increase in frequency of school inspection, discouragement of gratification being offered by principals and preparation of inspectors and teachers code of conduct on academic integrity were recommended.

Kolawole (2012) study indicated that significant relationship exist between principals and inspectors role on instructional supervision, inspectors and principals were alert to their responsibilities for improvement of instructions, possess the ability to work and actively engage in discharging their duties in terms of monitoring and evaluation.

Giwa (2005) study found out that the various role of inspectorate agencies were related to the need for maintenance of standards in our schools and colleges. Onasanya (2006) concluded that the inspectorate division should come up with innovations and be truly concerned with enhancement of learning and teaching in Nigerian schools. The government on the other hand should motivate the inspectors with attractive remuneration and logistics.

In a study conducted by Alade (2002), the input into the inspectorate services was not adequate for the organ of quality control to function effectively. Ekundayo, Oyerinde \& Kolawole (2012) concluded that successful inspector/supervisor should be knowledgeable about educational leadership, management and administration. They should know the culture of the schools and communities in order to ensure effective supervision. Supervisors of instruction should be knowledgeable of real life issues. Because, the role performance of the inspectors is necessary to improve the quality of education of a nation, it was deemed necessary by the author to determine the role performance by the inspectorate division to improve the standard of education in Adamawa State of Nigeria.

\section{Methodology}

This study adopted the ex-post factor survey design. To collect data from principals and teachers, a questionnaire tagged inspectorate role performance determination questionnaire (IRPDE) was used. The 23 items questionnaire consisted of six sections: background information, types of inspection visits, feedback on inspection, inspection reports, curriculum innovation and impact of inspection. The items from the fourmechanisms of role performance of inspectors were measured on a four point close ended response scale of "Always" to "Never". The items of the last section on the impact of inspection required a response on five point response Likert Scale of "Strongly Agree" to "Strongly Disagree". Role performance was determined using sources of evidence information from assessment of the existing mechanism for monitoring the performance of inspectors in the field and opinions of those who come into contact with the inspectors (Lillis, 1992) Split half method was use to determine the reliability of the instrument by correlating the scores or the subjects on odd and even items of the questionnaire. The overall reliability coefficient was 0.33 . The construct validity of the items was established by a computation, which produced correlation coefficient values that ranged from 0.11 to 0.93 . The analysis of items qualitatively and quantitatively retained 23 out of 27 items with coefficient of greater than or equal to 0.40 .

\subsection{Population and Sample}

The population of the study consisted of all principals as well as teachers from secondary schools in Adamawa State of Nigeria. Proportionate stratified sampling was used to select 60 principals and 60 teachers from the five inspectorate zones namely -Mubi, Gombi, Yola, Numan and Ganye of Adamawa State of Nigeria.

\subsection{Data Collection and Analysis}

Questionnaire was administered by five research assistants responsible for each of the five inspectorate zones of Adamawa State. Data were analyzed using Statistical package for social science (SPSS) version 16 . Hypotheses $1-5$ were tested through Z-test and hypotheses 6 was tested through factorial analysis of variance. Any hypotheses rejected indicates low role performance of the inspectorate division while accepted hypotheses show high role performance of the division in secondary schools. 


\section{Results}

The results of the investigation is presented in order in which hypotheses were raised.

Hypotheses I: There is no significant difference between the opinions of principals and teachers on types of inspection visits in secondary schools.

Table 1. Z- Test Difference between the Opinions of Principals and Teachers on Types of Inspection Visits in Secondary Schools

\begin{tabular}{lcccccc}
\hline Variables & $\overline{\mathrm{X}}$ & $\mathrm{SD}$ & $\mathrm{N}$ & Df & Z Value & $\mathrm{P}$ \\
\hline Principals & 4.20 & 0.96 & 60 & 11 & 5.21 & $\mathrm{~S}$ \\
Teachers & 2.50 & 1.60 & 60 & & &
\end{tabular}

P. 05.Level, $\mathrm{Z}=3.65$

$\mathrm{S}=$ significant

The data in table 1 shows that the $\mathrm{Z}$ value (5.21) is greater than the critical or table $\mathrm{Z}$ value. Therefore, this hypothesis which state that there is no significant difference between the opinions of principals and teachers on the types of inspection visit has been rejected. The result show significant difference between the opinions of principals and teachers on types of inspection visit. It also shows that the inspectorate division role performanceon conducting the types of inspection visits in secondary schools is low.

Hypothesis 2: There is no significant difference between the opinions of principals and teachers regarding feedback on inspection in secondary schools.

Table 2. Z Test Difference between the Opinions of Principals and Teachers Regarding Feedback on Inspection in Secondary Schools

\begin{tabular}{lcllllll}
\hline Variables & $\overline{\mathrm{X}}$ & $\mathrm{SD}$ & $\mathrm{N}$ & $\mathrm{df}$ & Z Value & $\mathrm{P}$ & \\
\hline Principals & 3.76 & 0.92 & 60 & 118 & 4.76 & $\mathrm{~S}$ & \\
Teachers & 2.12 & 1.10 & 60 & & & & \\
\hline
\end{tabular}

P. 05. Level, $Z=3.65$

$\mathrm{S}=$ significant

In table 2 , the $\mathrm{Z}$ - calculated was 4.76 while $\mathrm{Z}$ - critical was 3.65 .Since $\mathrm{Z}$ - calculated was higher than the $\mathrm{Z}$ critical, the null hypothesis was rejected. The result of the $\mathrm{Z}$ - test showed that there is significant difference between the opinions of principals and teachers on feedback on inspection. This shows that the inspectorate division role performance on inspection feedback is low.

Hypotheses 3: There is no significant difference in the opinions of principals and teachers on inspection reports in secondary schools.

Table 3. Z-Test Difference in the Opinions of Principals and Teachers on Inspection Reports in Secondary Schools

\begin{tabular}{|c|c|c|c|c|c|c|}
\hline Variables & $\bar{X}$ & SD & $\mathrm{N}$ & df & Z Value & $\mathrm{P}$ \\
\hline Principals & 4.70 & 0.53 & 60 & 118 & 2.09 & NS \\
\hline Teachers & 4.12 & 0.82 & 60 & & & \\
\hline
\end{tabular}

$$
\text { NS }=\text { Not Significant }
$$

In table3, the Z- calculated was 2.09 while $\mathrm{Z}$ - critical is 3.65 . The $\mathrm{Z}$ - calculated is lower than $\mathrm{Z}$ - critical. The result of the hypotheses was accepted. Z-test shows that there is no significant difference in the opinions of principals and teachers on inspection report on secondary schools. Opinions of principals and teachers has also revealed that role performance on inspection report in secondary schools is high.

Hypotheses 4: There is no significant difference between the opinions of principals and teachers on curriculum innovations in secondary schools. 
Table 4. Z-Test Difference between the Opinions of Principals and Teachers on Curriculum Innovations in Secondary Schools

\begin{tabular}{|c|c|c|c|c|c|c|}
\hline Variables & $\bar{X}$ & SD & $\mathrm{N}$ & $\mathrm{df}$ & Z Value & $\mathrm{P}$ \\
\hline Principals & 4.60 & 0.37 & 60 & 118 & 1.07 & NS \\
\hline Teachers & 4.25 & 0.62 & 60 & & & \\
\hline
\end{tabular}

The data in table 4 indicate that $\mathrm{Z}$ - calculated is 1.07 while Z-Critical is 3.65 . The hypotheses was accepted. The result $\mathrm{Z}$ - test shows no significant difference between the opinions of principals and teachers in inspecting secondary schools on curriculum innovation. It also indicates that the inspectorate division of the Ministry of Education performance in curriculum innovations in secondary schools is high.

Hypotheses 5: There is no significant difference in the opinions of principals and teachers on the impact of inspection on secondary schools.

Table 5. Z-Test Difference in the Opinions of Principals and Teachers on the Impact of Inspection in Secondary Schools

\begin{tabular}{lllllll}
\hline Variables & $\bar{X}$ & SD & N & df & Z Value & P \\
\hline Principals & 4.15 & 0.76 & 60 & 118 & 1.42 & NS \\
Teachers & 3.70 & 0.92 & 60 & & & \\
\hline
\end{tabular}

P. 05 level, $\quad Z=3.65$

NS $=$ Not Significant

Table 5 shows that Z-calculated is (1.42) lower than Z - critical (3.65). The hypotheses was accepted. The result of the $\mathrm{Z}$ - test show no significant difference in the opinions of principals and teachers in monitoring secondary schools. It also shows that the role performance of the inspectorate division onthe impact of inspection on the functioning of secondary schools is high.

Hypotheses 6: There is no significant difference between the opinions of principals and teachers on the five factors of role performance by the inspectorate division in secondary schools.

Table 6. Factorial Analysis of Variance on the Five Factors of Role Performance of the Inspectorate Division in Secondary Schools

P.05 level, $\mathrm{F}=3.35$

\begin{tabular}{lllll}
\hline Variables & MS & DF & F & P \\
\hline Nature of inspection & 653.9 & 3 & 4.10 & S \\
Feedback on inspection & 421.6 & 3 & 3.75 & S \\
Inspection reports & 768.3 & 3 & 5.21 & $\mathrm{~S}$ \\
Curriculum innovations & 743.2 & 3 & 4.76 & $\mathrm{~S}$ \\
Impact of school inspection & 682.5 & 3 & 4.30 & $\mathrm{~S}$ \\
\hline
\end{tabular}

$\mathrm{S}=$ significant

Table 6 shows that all the five factors are significant with a F-calculated value of 4.10,3.75,5.21,4.76 and 4.30 each and F - critical value of 3.35. This hypotheses has been rejected. This result shows that principals and teachers differ significantly on the five factors of role performance of the inspectorate division in secondary schools. It reveals that the inspectorate division role performance on the five factors of performance in secondary schools is low. 


\section{Discussion of Findings}

Results from table I shows that the null hypotheses was rejected. This means that the inspectorate division of the ministry of Education performance on types of inspection visits in secondary schools is low. Any observed role performance is due to chance. This result differs from the findings of Kolawole (2012) which found that inspectors are alert to their responsibilities for improvement of instruction, possess the ability to work adaptively, engaged in discharging their duties in terms of the types of inspection visits. Ochuba (2013) agreed with the findings that inspectorate services at the state and federal levels have notlived to expectation in terms of conducting the types of inspection visits in secondary schools. This may be as a result of human relation movementlaize - faire supervision from inspectors which they let people do things in whatever ways they well wish to which can infact also lead to under productivity (Sergiovanni\&starrat; 1983; 2007; Wertheim, 2007).

The finding in hypotheses 2 and table 2 indicate that there is significant difference in the opinions of principals and teachers on feedback on inspection in secondary schools. This is in disagreement with Giwa (2005) which states that the major role performed by the inspectorate division of the Ministry of Education is feedback on inspection in secondary schools. Shaheen (2013) is consistent with the findings that teachers do not perceive feedback given by inspectors in making improvement in their work performance. This may be linked to the critical theory where inspectors recognise that teachers are free entities with their own thinking, their role as school inspectors is to facilitate the teaching/learning processes and not to dictate what should be done by the teachers(Tripp, 1992).

Thereis no significant difference in the opinions of principals and teachers on inspection report in secondary schools as indicated in the findings of hypothesis 3 table 3. This confirms the assertion from Shaheen (2013) that teachers perceive the advice given through inspection reports. This did not concur with the finding of Badau (1992) that inspection reports are not use for evaluating principals and teachers in secondary schools in Gongola State of Nigeria. This finding is backed by scientific management theory that workers need to comply and they don't need autonomy or freedom of thought but instead their role was simply to follow the direction of their superiors in order to be efficient (Sergio vanni \& Starrat, 1993; Welsh \& Mcginn, 1999).

The findings with regards to hypotheses 4 table 4 show no significant difference between the opinions of principals and teachers on curriculum innovations. This did not agree with the assertion of Alade (2002) that there were no qualified inspectors to control curriculum innovations in the education system in Lagos state of Nigeria. Scientific Management theory supported the finding that teachers cannot be left free to do whatever she/he wishes to do. Some rules and regulations are to be applicable with a mixture of humanity, if the national goals and objectives are to be achieved (Serogiovanni \& Starrat, 1993).

The findings in respect of hypotheses 5 table 5 is that no significant difference exist in the opinions of Principals and teachers on impact of inspection. This corroborates with Grauwe and Carron (2008) believe that educational system monitoring by inspectors has impact on secondary schools. This findings may be as a result of scientific management view that management felt that workers are lazy and needed to be pushed or coerced, workers had to be closely supervised (Serogiovanni\&Starrat, 2007).

There was a significant difference recorded in the opinions of principals and teachers on the role performance of the inspectorate division of the Ministry of Education on factors of performance (Hypotheses 6 table 6). This has been confirmed by the assertion of Ekundayo, Oyerinde and Kolawole (2013) which shows that inspectors role performance is low. This finding may be as a result of human relations view that teachers have initiatives that they could perform on the job without close supervision (Druker, 1991). The findings might have resulted from critical theory view of giving more voice to teachers as key players and implementers of curriculums. Hence, the view of scientific management that human beings have little desire for responsibility, they prefer to be directed in order to make inspectors performance high.

\section{Conclusion}

This paper concluded that inspectorate division of the Ministry of Education role performance on types of inspection visits and feedback on inspection in secondary schools is low. This may have resulted from human relations and critical theory, which advocates democratic and emancipation process. Inspectors who need to be coerced now have freedom to do what they want which can lower performance on type of inspection visits and feedback on inspections. The inspectorate division role performancein producing inspection reports, controlling curriculum innovations and impact of inspection on functioning of secondary schools is high. The view of scientific management of strict supervision might have resulted to high performance in the findings. It indicates inspectors bureaucratic roles and 
consistent with the scientific inspection approach taken over by the Ministry of Education. Furthermore, these finding contribute to the literature on scientific inspection. Generally, the inspectorate division of the Ministry of Education role performance on the five factors of performance in the secondary schools is low. This shows that the inspectorate division of the Ministry of Education role performance in secondary schools is generally low in Adamawa State of Nigeria. Modern inspection involve as a result of human relation movement that workers have initiative that they could perform well on the job without close supervision and they could be efficiently and effectively be mobilized towards mass production without being coerced or forced. This view also encourages cooperative practice in supervision. These findings showed that some inspectors represent their rigid bureaucracy in Adamwa State of Nigeria, while some sows humanistic management roles.

\section{Recommendations}

The following recommendations are made based on the findings of the study.

1. The Inspectorate division of the Federal and State Ministries of Education should conduct all types of inspection visits frequently in order to inspect all aspects of secondary educational system.

2. Feedback should be given to secondary school teachers for improvement after inspection in secondary schools.

3. A comprehensive inspection report covering all different dimensions of secondary school functioning should be provided at the end of inspection.

4. Curriculum innovations should be controlled by inspectors through implementation and the recommendation of text books in secondary schools.

5. The role performance of inspectorate division in system evaluation should be increased so that it can have impact on school functioning to improve the quality of the secondary educational system.

6. Adequate and qualified human and material resources should be provided by the Federal and State Ministries of education to make therole performance of the Inspectorate division of the Ministry of Education high in secondary schools.

\section{References}

Afrosale. (2013). Inspection and supervision of secondary schools performance audit. Freetown: Sierra Leone.

Aiyepeku T.F. (1982). The problems of the inspectorate Services: Report of the Sub-Committee of the J.C.C. on Education. In the inspector; F.M.E. Lagos Vol. 2, 2001.

Aiyepeku, T.F. (1983). School Inspection and quality control. Ibadan: University of Ibadan press.

Aiyepeku, T.F. (1987). Functions of an Inspector. Ibadan: University of Ibadan press.

Alade O. M. (2002). Needs Assessment of the Education inspectorate: A case study of Lagos State Nigeria. A paper presented at the $2^{\text {nd }}$ regional conference of Higher Education Research and Policy Network (HERPNET) at Ibadan.

Badau, K.M. (1992). A study of the Role Performance of the inspectorate Division in secondary schools in Gongola State. M.ED thesis submitted to University of Maiduguri, unpublished.

Calos, E. O. (1984). The role of the school inspectorate in plan implementation: a systematic approach. Coastarrica.

Carr, W., \& Kemmis, S. (1986). Becoming critical, education, knowledge and action research. Biwess Palmer influential books.

Chapman C. (2001). Unlocking the potential: Inspection as a mechanism for school improvement. Sage Journals, 4(3), 60-71.

Druker, P. (1991). Managing the nonprofit organization: practices and principles. New York: Harper Collins.

Ekundayo, H.T., Oyerinde, D.O., \& Kolawole, A.O. (2013). Effective supervision of Instruction in Nigerian Secondary Schools: Issues, Challenges and the way forward. Journal of Education and practice, 64(8), 185-190.

Erhren, M.O., Leeun, F., \& Scheereng, J. (2008). On the impact of the Dutch Educational Supervision Act on managing assumptions concerning the inspection of primary education. America Journal of Evaluation, 26(1), 
60-76. http://dx.doi.org/10.1177/1098214004273182

Federal Ministry of Education. (1985). Federal Inspectorate service. Abuja: Federal Government Press.

Federal Republic of Nigeria. (2008). National Policy on Education. Lagos: Federal Government Press.

Giwa, F.O. (2005). The concept of supervision and the supervisors role in the Nigerian Educational System. Educational Journal, University of Ilorin.

Gokce, A.T., \& Kantos, Z.E. (2012). Primary school perception of inspectors and inspection period in Turkey. Meditranean Journal of Social Sciences, 3(3), 199-202.

Grauwe A.D. (2007). Performing school supervision for quality improvement. Paris: UNESCO.

Hommeier, W., \& Kluth, J. (2011). The impact of inspection.Lower Saxony. Presentation on S.I.C.I. Workshop from $23^{\text {rd }}-25^{\text {th }}$ November, 2012 in Stock hold, Sweden.

Ijaiya, N. Y. S., \& Fasasi, Y.A. (2008). Teachers perception of secondary school inspectorsintegrity in Kwara State. The African Symposium.

Klerks, M. C. J. L. (2012). The effect of school inspections; A systematic review. Paper presented at the ORD, Nageningen, the Netherlands.

Kolawole, A.O. (2012). Comparative Study of Instructional supervisory roles of secondary school principals and inspectors of the Ministry of Education in Lagos State, Nigeria. European Scientific Journal, 8(28), 37-45.

Lillis, K. M. (1992). Improving basic education; A reconditions for successful inspection and supervision. Implication for training. Paris: IIEP.

Longe, R. S. (1986). The functional dependant of educational planning on school supervision. African Journal of Management, 1(1), 66-77.

Maccrone, J., Rudd, P. Blenkinsop, S. Wade, P., Rutt, S., \& Yestianewe, T. (2017). Impact of OFSTED edition 5 inspections; maintained schools in England; final report.

Machumu, H. J. (2012). Secondary school teachers attitude towards school inspection: A case study of Bunda District Council in Tanzania. European Scientific Journal, 9(25), 30-36.

MacIsaac, M. (1996). Handbook of I.S. Management. Hardcover, Ebaycompany.

Matete, R.E. (2009). Research Report, Faculty of Educational Science, University of Tsawane, South Africa.

Njoku, C. (1983). A guide to effective supervision of instruction in Nigeria schools. Lagos: Manbay publishing company.

Obemata, J.O. (1995). Education.An unprofitable Industry in Nigeria. A post-graduate school inter-disciplinary Discourse. University of Ibadan, Nigeria.

Ochuba, V.O. (2009). Improve the quality of Education in Nigeria through effective inspection of schools. Academic Journal, 129(4), 144-155.

OFSTED, (2007). Review of the impact of inspection. Ref. No. 070042. Retrieved from http:www.ofsted.governent.uk/resources, impact report 2007

Onasanya, S.A. (2006). The concept and practice of supervision/inspection in Kwara State public primary schools. Journal of Education, 4, 40-55.

Oyedejo, N.B. (2008). Supervision and standard of Education in Nigerian Secondary Schools. Department of Educational Management Journal, 1(1), 80-95.

Rai, A.K., \& Singh, S. (2013). School supervision: Roles and Difficulties. International Journal of Education, 3(2), 58-65.

Riches, C. (1992). Inspecting the inspection of schools. Sage Journals, 6(2), 15-25.

Rosenthal, L. (2004). Do school inspection improves school quality? OFSTED inspection and school examination results. Economist of Education review, 23, 143-151. http://dx.doi.org/10.1016/S0272-7757(03)00081-5

Sergiovanni, T.T., \& Starraft, R.J. (2007). Supervision: A redefinition ( $8^{\text {th }}$ Edition). Newyork: Mcgraw Hill.

Shaheen, Z. (2013). Role and Effectiveness of Academic Monitoring in the Development of Schools. Journal of academic Research International, 4(5), 571-579. 
Shaheen, Z. (2013). Role and Effectiveness of Academic Monitoring/Inspection in the development of schools. European Journal of Education and learning, 1(5), 6-65.

The United Republic of Tanzania (2008). When school inspection doesn't deliver.Highlights from the CAG audit of the secondary schools programme in Tanzania.

Tripp, S. (1992). Michael oakeshotts, philosophy of education and its implications for instruction design theory and practice. ERIC Journals, 1-19.

Tunde, A. (1980). The role of the modern inspector in relation to the aims and objective of school inspection in the Inspectorate Journal of the Federal Inspectorate services. Federal Ministry of Education, Lagos.

Welsh, T., \& Mcginn, N. (1999). Decentralization of education; why, when, what and how? Paris: IIEP.

Wertheim, E.H. (2007). Internet - delivered dissatisfaction and disordered eating in adolescent girls. A randomized control trial. Journal of Abnormal child-psychology, 35, 379-39. http://dx.doi.org/10.1007/s10802-006-9097-9 